\title{
Carbon dioxide reduction in housing: experiences in urban renewal projects in the Netherlands
}

\author{
Jochem F M van der Waals \\ Ministry of Housing, Spatial Planning and the Environment, PO Box 30945, 2500 GX, \\ The Hague, The Netherlands; e-mail: jochem.vanderwaals@minvrom.nl \\ Walter J V Vermeulen, Pieter Glasbergen \\ Copernicus Institute, Department of Environmental Studies and Policy, Utrecht University, \\ PO Box 80115, 3508 TC, Utrecht, The Netherlands; e-mail: w.vermeulen@geog.uu.nl, \\ p.glasbergen@geog.uu.nl
}

Received 22 February 2002; in revised form 25 October 2002

\begin{abstract}
It is increasingly being recognised that the housing sector can contribute to reductions in the levels of carbon dioxide $\left(\mathrm{CO}_{2}\right)$. The renewal of existing residential areas offers opportunities to reduce $\mathrm{CO}_{2}$ emissions. However, technical options for $\mathrm{CO}_{2}$-reduction, such as insulation, solar energy, and combined heat and power, often fail to materialise. For a better understanding of why options for $\mathrm{CO}_{2}-$ reduction are applied or rejected, it is insufficient to consider only the economic and technical features of these options themselves: factors related to planning processes play an important role as well. Experiences in urban renewal projects suggest that a combination of local process management and national top-down strategies is needed to go beyond conventional building practices.
\end{abstract}

\section{Introduction}

The reduction of carbon dioxide emissions $\left(\mathrm{CO}_{2}\right.$-reduction) has gained a prominent place on the agenda of environmental policies. A central aim of strategies for $\mathrm{CO}_{2-}$ reduction is often to stimulate the adoption of technological innovations. These innovations need to be adopted in networks of interdependent actors that are not primarily concerned with $\mathrm{CO}_{2}$-reduction. These characteristics also hold for the housing sector, which is increasingly being recognised as a key sector for $\mathrm{CO}_{2}$-reduction. The renewal of existing residential areas is one of the fields with opportunities for $\mathrm{CO}_{2}$ reduction. However, technical options for $\mathrm{CO}_{2}$-reduction, such as insulation, solar energy, and combined heat and power, often fail to materialise.

It is widely believed that this is related to the costs and technical feasibility of options for $\mathrm{CO}_{2}$-reduction. This is, however, only a partial explanation. For example, double glazing, a well-known and relatively cheap option, is sometimes not applied when houses are renovated, whereas there are examples of the successful adoption of more expensive techniques, such as photovoltaic systems. A closer look at the planning processes of urban renewal projects gives more insight into the factors underlying such outcomes. In this paper we address the following question: what is the relative influence of the factors related to planning processes and of the perceived technical and economic characteristics of options for $\mathrm{CO}_{2}$-reduction on the degree to which they are adopted in urban renewal projects? The following analysis is based on empirical research conducted in the Netherlands.

\section{The potential for $\mathrm{CO}_{2}$-reduction in housing}

Before discussing the research approach and results, in this section we give some background information about the potential for $\mathrm{CO}_{2}$-reduction in housing. $\mathrm{CO}_{2}$ emissions caused by dwelling-related energy consumption amounted to about 23 million tonnes in 2000, which is $12 \%$ of the Netherlands' $\mathrm{CO}_{2}$ emissions (CBS/RIVM, 1999; 
Crommentuijn and Verbeek, 1999). By 'dwelling-related energy consumption' we mean that part of energy consumption that is influenced by the technical condition of houses. This involves natural-gas consumption and a small part of electricity consumption, but excludes the energy used for domestic electrical appliances. The bulk of gas consumption (about $75 \%$ ) is used for heating, the remainder being related to the provision of hot water $(20 \%)$ and cooking $(5 \%)$.

Many technical measures are available to reduce $\mathrm{CO}_{2}$ emissions. These can be divided into construction measures, measures regarding the installations, and, for new housing, options for the energy infrastructure (see table 1). Because of this diversity of options, a comprehensive approach is necessary, taking into account the interconnections between choices at different spatial levels. Some options are relatively cheap (for example, high-efficiency condensing boilers, double glazing), whereas others are just emerging from the experimentation stage and are still relatively expensive (photovoltaic systems, heat pumps).

Table 1. Options for $\mathrm{CO}_{2}$-reduction in housing (source: Boonekamp et al, 2000; Slot et al, 1998; van der Waals, 2001).

Type of measure Option

Construction measures

cavity-wall insulation

floor insulation

roof insulation

exterior-wall insulation

double glazing

high-performance glass

Installations

high-efficiency condensing boiler

water-saving measures

metering of energy use of separate houses

solar domestic hot water systems

balanced ventilation with heat recovery

individual heat pump

energy-efficient lighting

Energy infrastructure

small-scale combined heat and power

district heating

collective heat pumps

At the construction level, insulation and glazing are important. High-performance glass has a transparent metal costing that reflects warmth, and is more effective than double glazing in diminishing heat loss. At the installation level, installation of highefficiency condensing boilers is a common measure. More advanced options include solar domestic hot water systems and heat pumps.

At the energy infrastructure level, district heating is a technique that uses the surplus heat from electricity plants or other sources for space heating and for hot water. A small-scale combined heat and power (CHP) system is used for blocks of houses ranging from 40 to 300 dwellings, and uses the heat produced by smaller gas engines that are installed in the urban area. Application of CHP usually leads to lower $\mathrm{CO}_{2}$ emissions than those from a conventional gas system. Metering the energy use of separate houses is a precondition for this.

Several studies show that in the existing housing stock, a considerable $\mathrm{CO}_{2}$-reduction is technically feasible. A study by Slot et al (1998) estimated potential reductions of between $13 \%$ and $44 \%$, depending on the extensiveness of measures. This would imply a reduction of 3.1 to 10.6 million tonnes of $\mathrm{CO}_{2}$ for the 6.2 million Dutch houses 
existing in 1995. However, the investment costs for ambitious packages of options are high and average pay-back periods are long, at least in a situation where energy prices are-even with energy taxes-relatively low.

This suggests that a drastic improvement involving large-scale application of innovative techniques is not realistic. However, an investment averaging just $€ 954$ per house could secure a $\mathrm{CO}_{2}$-reduction of $13 \%$ (3.1 million tonnes). It must be stressed that this is an average figure, and that the investments needed differ from house to house (Slot et al, 1998).

Another study by ECN/RIVM (1998, pages 56-59) estimates that a potential $\mathrm{CO}_{2}$ reduction of $15 \%$ (3.6 million tonnes) could be achieved with a legal requirement for energy efficiency introduced in existing houses, and that an average of $€ 2300$ per dwelling would need to be spent to achieve this standard.

\section{Conceptual model}

A conceptual model was developed which combined two theoretical bodies of knowledge: the literature about policy networks; and the literature about diffusion of innovations. This combination was chosen because options for $\mathrm{CO}_{2}$-reduction can be seen as innovations that need to be adopted in a planning process that evolves in the context of a policy network.

The policy network is a central concept in policy studies (see Kickert et al, 1997; Marin and Mayntz, 1991). Scharpf (1978, page 347) uses the concept to interpret the limitations to central governance in a context of growing societal integration and organisational fragmentation. The essence of the concept is the recognition that different actors with diverse motives and interests depend on each other to achieve their goals. Kickert et al (1997, page 6) define policy networks as "more or less stable patterns of social relations between interdependent actors, which take shape around policy problems and/or policy programmes". The mutual dependencies arise from the fact that to realise their ambitions actors need the resources of others, such as authority, financial means, information, land, support, and legitimacy (Teisman, 1998, pages $43-65)$.

In the literature about the diffusion (dissemination and application) of innovations, several definitions of innovation can be found. Rogers (1995, page 11) defines an innovation as an idea, practice, or object that is perceived as new by an individual or other unit of adoption. (Adoption is the decision by an individual actor to apply an innovation.) Rogers claims that a technological innovation usually has two components: a hardware aspect, consisting of the tool that embodies the technology as a material or physical object; and a software aspect, consisting of the information base for the tool (Rogers, 1995, page 12). Smits (2000, page 10) defines an innovation in broader terms, as a socially and/or economically successful combination of hardware (the device), software (the idea), and orgware (the organisational and institutional conditions). Policy networks can be seen as part of the 'orgware' component of innovations.

In our conceptual model the adoption or nonadoption of options for $\mathrm{CO}_{2}$-reduction is deemed to be the explained variable (figure 1, see over). It is assumed that it is influenced by three sets of explanatory variables: characteristics of options for $\mathrm{CO}_{2-}$ reduction; factors related to planning processes; and external factors. Our research aimed to establish the relative influence of each of these factors, particularly of the perceived technical and economic characteristics of options for $\mathrm{CO}_{2}$-reduction and of the factors related to planning processes. 


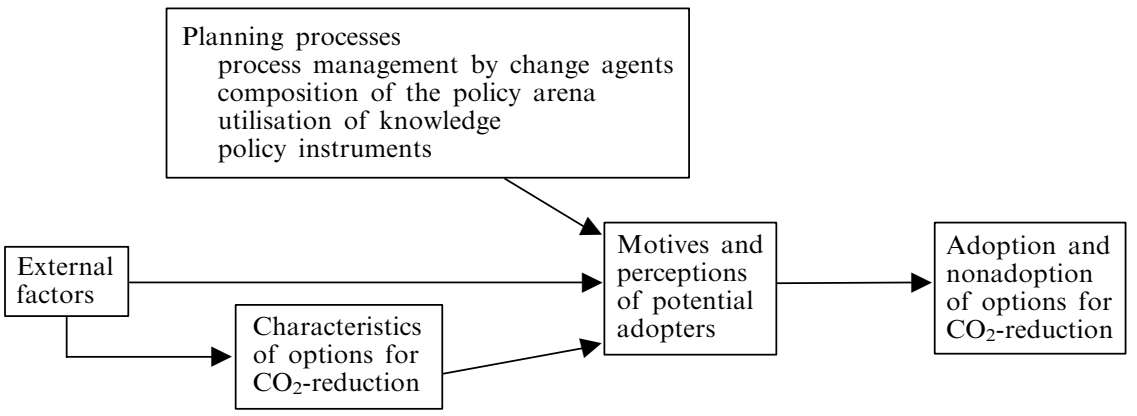

Figure 1. Conceptual model.

\subsection{Characteristics of options for $\mathrm{CO}_{2}$-reduction}

Options for $\mathrm{CO}_{2}$-reduction differ widely according to their economic characteristics. The investment costs of these options are related to the technical characteristics of the options and of the houses and energy systems that are already in use. Characteristics may also be described in other than economic and technical terms, such as relative advantage, compatibility, complexity, trialibility, and observability (Rogers, 1995, pages $15-16)$.

\subsection{Factors related to planning processes}

These can be divided into the following explanatory variables:

(1) Process management by 'change agents'. According to Rogers (1995, pages 335 - 370), a 'change agent' is an individual who stimulates the adoption of innovations. In our study, a change agent was defined as an organisation or individual that tries to induce potential adopters to play their part in the adoption of options for $\mathrm{CO}_{2}$-reduction. Process management can be defined as a management strategy that involves communication and cooperation between actors who are invited to provide input in the decisionmaking process.

(2) The composition of the policy arena, that is, the actors that are involved in the planning process (see Teisman, 1998, page 52).

(3) The utilisation of knowledge in the planning process. This was mainly interpreted as the existence of scientific studies that involve a systematic comparison of applicable options for $\mathrm{CO}_{2}$-reduction in the project concerned, and the way such studies were dealt with in the planning process.

(4) The policy instruments that are applicable — such as regulations, subsidies, and covenants.

\subsection{External factors}

External factors are factors that influence the chances of the options being adopted, but are difficult for actors in local planning processes to influence. These may include liberalisation of the energy market, growing environmental awareness in the building sector, and developments in the housing market.

The three sets of variables influence adoption or nonadoption indirectly through an intermediary variable, namely the motives and perceptions of potential adopters. The motives of potential adopters are the objectives they seek to achieve, such as making financial profits, realising aesthetic quality, protecting the environment, or solving social problems. Two kinds of perception are important: the perceptions of options for $\mathrm{CO}_{2}$-reduction, and the susceptibility of potential adopters to incentives from other actors aimed at ensuring adoption of options for $\mathrm{CO}_{2}$-reduction. 


\section{Research methods and selection of case studies}

To investigate the influence of the explanatory variables on the adoption or nonadoption of options for $\mathrm{CO}_{2}$-reduction, four case studies of urban renewal projects were conducted. The study was financed by the Dutch Ministry of Housing, Spatial Planning and the Environment. For a more extensive analysis, see van der Waals et al (2000) and van der Waals (2001).

In the selection, 'urban renewal' was defined as a combination of measures at the level of an existing urban neighbourhood or district aimed to improve the housing stock and the living environment (infrastructure, facilities, social projects). Urban renewal may include improvement of existing dwellings as well as building of new dwellings. The emphasis in our research was on renovation, but attention was also given to the building of new houses.

Thirty-eight face-to-face interviews were conducted with municipal project managers, aldermen in the housing field, local civil servants, project managers of housing corporations, a housing developer, architects, and representatives of energy-distribution companies. The individuals selected were those who played a role in decisionmaking according to the information given by actors themselves. The interviews were based on a semistructured questionnaire. In addition to the interviews, a number of documents were analysed, such as master plans, policy documents, evaluations, research reports, programmes of requirements, etc.

A preexisting survey was used to obtain information about the large number of urban renewal projects in the Netherlands (Moorman, 1999). This survey included 83 urban renewal projects that were being prepared or realised in 1999 and involved at least 100 dwellings. The case studies [see table 2 and figure 2 (over)] were selected from this group of projects.

Table 2. The four case-study areas.

\begin{tabular}{llllc}
\hline & $\begin{array}{l}\text { Flatstrook } \\
\text { Groenewoud }\end{array}$ & Millinxbuurt & $\begin{array}{l}\text { Utrecht }- \\
\text { Noordwest }\end{array}$ & Malburgen \\
\hline City & Spijkenisse & Rotterdam & Utrecht & Arnhem \\
Researched period & $1990-99$ & $1996-99$ & $1990-99$ & $1995-99$ \\
Number of houses built & 403 & 50 & 1900 & 2800 \\
Number of renovated houses & 423 & 600 & 600 & 200 \\
Social rented housing & yes & yes & yes & yes \\
Owner-occupied housing & no & yes & yes & yes \\
Private rented housing & no & yes & no & yes \\
& & & &
\end{tabular}

One of the selection criteria was that 'successful' as well as 'unsuccessful', from a $\mathrm{CO}_{2}$-reduction perspective, projects needed to be included. The definition of success depended on the degree to which options were systematically applied (see section 5). Another criterion concerned the representation of different segments of the housing market (social rented, private rented, and owner-occupied housing). The final criterion was that the projects needed to be finished or being implemented.

The urban renewal projects addressed similar problems, relating to the quality of the housing stock, the social situation, and the spatial structure of the area. A central goal was to create a more varied housing stock and a population that also included people with higher incomes. For this purpose, some houses were improved, and others were demolished and replaced with new houses. All the urban areas faced social problems such as crime, unemployment, and drug abuse. In Flatstrook Groenewoud and Millinxbuurt in particular, these problems were severe. Therefore, the projects also aimed to improve social safety. The projects were coordinated by the municipality and 


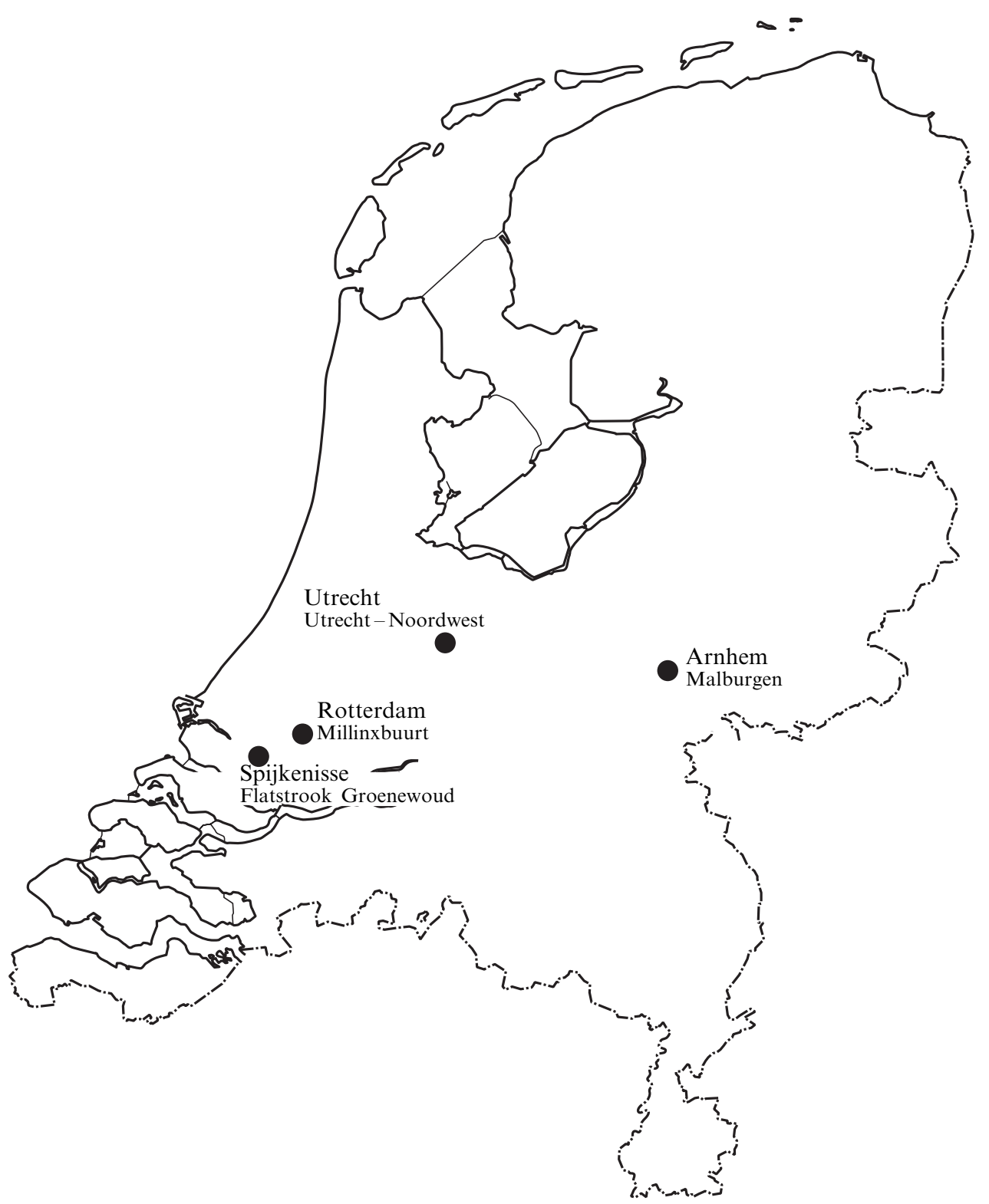

Figure 2. Locations of the case-study areas.

carried out in public-private partnerships with housing corporations or housing developers.

\section{Adoption of options for $\mathrm{CO}_{2}$-reduction}

Urban renewal projects consist of several subprocesses related to specific activities, such as preparation of a masterplan, making plans for public space, preparing a renovation project, etc. The four cases were subdivided into twelve subprocesses. A distinction was made between 'successful' and 'unsuccessful' subprocesses, based on the following criteria:

(a) Those renovation projects in which in all houses at least two parts of the house shell were insulated, and energy-efficient heating installations were installed, and 
high-performance glazing was applied were defined as successful. The projects in which only one of the three elements (construction, glazing, installations) was improved, or in which two of these elements were improved but only in a limited number of houses, were regarded as unsuccessful.

(b) The planning processes for new housing blocks in which options were applied that went further than the Energy Performance Standard (EPN) required at the time were regarded as successful examples. The EPN is a legal requirement that prescribes a minimum level of energy efficiency of new dwellings. It is a calculated measure that weighs energy-saving measures in a dwelling or building.

(c) There were two planning processes regarding the energy infrastructure in projects where a large number of new houses were built (Malburgen and Utrecht-Noordwest). The processes in which a gas grid was chosen were seen as unsuccessful examples (Malburgen). Likewise, the processes in which district heating or small-scale CHP was supplied to least $50 \%$ of the planned houses were defined as successful (Utrecht-Noordwest).

As regards the adoption of options for $\mathrm{CO}_{2}$-reduction, there appeared to be some variation between, as well as within, the urban renewal projects. However, in general, many opportunities for $\mathrm{CO}_{2}$-reduction were being missed. A number of options for $\mathrm{CO}_{2}$-reduction were being applied, particularly insulation, condensing boilers, and high-performance glass, but the options were often applied to only some of the houses or to part of the house shell. The survey mentioned in the previous section was used to check whether these findings also hold for urban renewal practice in the Netherlands in general. This appeared to be the case.

In the following section we discuss the explanations for the pattern of adoption and nonadoption, as revealed in the case studies. We then discuss the influence of the three factors described in our conceptual model: characteristics of options for $\mathrm{CO}_{2}$-reduction, factors related to planning processes, and external factors (see figure 1).

\section{Characteristics of options for $\mathrm{CO}_{2}$-reduction}

Some authors state that economic and technical factors explain whether options for $\mathrm{CO}_{2}$-reduction are adopted or not. From an economic point of view, a firm or a household will invest in energy conservation up to the point where the financial benefits no longer outweigh the costs (Velthuijsen, 1997, page 15). Because the investment costs of options for $\mathrm{CO}_{2}$-reduction are to some degree related to the technical options, Capello et al (1999, pages 75-85) speak of techno-economic features. They claim that the main obstacles to the transition to renewable energy systems lie in their techno-economic features, which influence the adoption costs and revenues.

The case studies showed that in situations where no or few options for $\mathrm{CO}_{2}$-reduction were adopted, costs were often seen as a barrier. However, this concern related to impressions of costs at face value, rather than any consideration of the actual costs and benefits. Advantages and disadvantages of options were often not explicitly weighed in the urban renewal projects. Options received little attention, regardless of whether they were cost-effective. The main reason for this was that actors focused on other issues, such as spatial quality, economic development, housing objectives, or the solution of social problems, and thus did not seriously consider options for $\mathrm{CO}_{2}$-reduction.

Technical and physical constraints also proved to be a barrier, although their impact was limited to specific options and situations. Examples in the renovation projects were a crawlspace that could not be insulated, and suboptimal orientation of the roof for solar domestic hot water systems. In Malburgen, the small number of houses to be built, the fact that they were divided among different small projects, and the long building period, were seen as a barrier to cost-effective operation of combined 
heat and power systems. There are also examples of technical facilitating factors, such as the presence of an existing district heating grid, which made it easier to opt for district heating in Utrecht - Noordwest.

In the 'successful' planning processes, options were applied for reasons other than the perceived economic benefits: the improvement of the physical housing quality and level of comfort resulting from insulation and double glazing were more important motives.

In some cases, options were applied with the aim of experimenting with new techniques (in Rogers's terms, because of their 'trialibility', see section 3). The 'observability' (see section 3) of options for $\mathrm{CO}_{2}$-reduction was not a decisive factor in most situations, and was more often a barrier than an advantage.

We can conclude that in order for options for $\mathrm{CO}_{2}$-reduction to be adopted in urban renewal projects, it is necessary for the potential adopters to recognise advantages other than economic and technical ones of options for $\mathrm{CO}_{2}$-reduction, particularly the degree to which they contribute to comfort and the improvement of housing quality. However, this observation does not explain why options appeared on the agenda in some projects but not in others, and how decisions about adoption or nonadoption were made. In the next section, therefore, we discuss the factors related to planning processes to address these questions.

\section{Factors related to planning processes}

In this section we discuss the impact of process management by change agents, the composition of the policy arena, the utilisation of knowledge, and policy instruments.

\subsection{Process management by change agents}

In the more successful projects in Malburgen and Utrecht-Noordwest, processmanagement strategies by 'change agents' (see section 3) played an important stimulating role. These change agents were not part of the original policy arena, but themselves took the initiative to play an active role. Their process-management strategies involved placing the innovation on the agenda, negotiating with potential adopters about the division of costs, extending the policy arena to actors that were not previously involved, and commissioning research into possible options. Where change agents were absent, less options were applied, although in some renovation projects in the social rented sector, some-more conventional-options were adopted.

In the Utrecht-Noordwest case, different actors can be viewed as change agents. Two of these are a consultancy firm and a housing corporation, who initiated a demonstration project for energy conservation which was largely financed by the Thermie programme of the European Union. In a block of 248 houses, they aimed for a $\mathrm{CO}_{2}$-reduction of 50\% compared with 1998 levels. The two actors contacted the energy-distribution company to ask whether the existing district heating system could be extended to the area. The energy-distribution company wanted to cooperate with this, assumed the role of change agent, and started negotiations with housing developers. After difficult negotiations about the division of costs, the developers went along with the construction of district heating. Remarkably, the municipality was not involved in the process.

A second example of a change agent is the Energy Agency in Malburgen - a foundation in which municipal departments and other local actors cooperate, with subsidies from the European Union. The task of the Energy Agency was to develop and implement the local energy policy. In Malburgen, it was successful in some cases, but not in others. The Energy Agency advised the housing corporation on options for $\mathrm{CO}_{2}$-reduction and possibilities for financing them in a renovation project of 200 
houses. This contributed to the comprehensive package of measures taken, including good insulation and solar domestic hot water systems.

The Energy Agency also commissioned a research institute to investigate options for the energy infrastructure for the 2800 new houses, and involved the housing corporation, the energy-distribution company, and others in the policy arena to discuss the results. According to the research, the application of small-scale CHP would be possible. However, the energy-distribution company proposed the construction of a gas system because of the technical and economic difficulties related to CHP. No clear decision was taken, partly because of a lack of adequate coordination of the decisionmaking process.

\subsection{Composition of the policy arena}

As discussed in section 3, a second explanatory variable related to planning processes is the composition of the policy arena, that is, the actors that are involved in the planning process. In the Netherlands, $36 \%$ of the housing stock consists of social rented housing (DGVH, 1999). Therefore, housing corporations-licensed organisations with the legal task of providing housing for people with lower incomes-play an important role in urban renewal projects. Other actors involved include municipal departments (urban planning, housing, social affairs, and employment), politicians, architects, residents, and - in some cases - the police and social work organisations. The motives of these actors primarily concerned the improvement of the physical and social environment, which is understandable given the urgency of the problems in these fields. Because $\mathrm{CO}_{2}$-reduction was not an important motive for these actors, in none of the projects did the issue come on the agenda early in the planning process. In most cases the energy-distribution company and the department of environmental affairs, who could have advised on energy aspects, were not involved in the policy arena.

Specific problems may arise when the policy arena is characterised by the presence of many private house owners. If a municipality desires far-reaching measures that go beyond the requirements of the Building Decree, it has to negotiate with house owners. In the Millinxbuurt project, the department of building control, which coordinated the renovation, did not want to engage in lengthy negotiations and the private landlords were not willing to invest in energy efficiency. A second problem was the fact that decisions about the collective facilities in a housing block are made by associations of house owners, which often function badly. If not all owners agree, problems can arise: for example, wall insulation may lead to moisture problems in multistorey housing complexes if it is not applied in every apartment.

In Malburgen, the department of urban planning coordinated a renovation for a flat complex of thirty-six dwellings. It investigated possible options and discussed them with the residents. The discussion took place in the owners' association, made up of twenty-four owner-occupiers, twelve private landlords, and the municipality, which had bought the shop space on the ground floor. The package of measures chosen was less ambitious than the municipality had proposed. All owner-occupiers advocated a more drastic renovation, but the private landlords considered this too expensive as they calculated shorter pay-back periods. The landlords were able to obstruct the more ambitious proposals because the association requires consensus for decisions about collective facilities. Nevertheless, if the municipality had not taken the initiative, many options would probably not even have been considered, regardless of whether they were cost-effective or not.

It appears that the success of the efforts of change agents depends on the motives and perceptions of the other actors in the policy arena. However, the influence of the composition of the policy arena is not simply related to the question of whether specific 
actor groups participate or not, as different actor groups may play a stimulating or restraining role. The presence of many house owners may form a barrier to adoption of options for $\mathrm{CO}_{2}$-reduction, particularly if small-scale private landlords are involved.

\subsection{Utilisation of knowledge}

The variable 'utilisation of knowledge' was mainly interpreted as the existence of scientific studies that involve a systematic comparison of applicable options for $\mathrm{CO}_{2}$-reduction, and the way such studies were dealt with in the planning process.

The case studies showed that the advantages and disadvantages of options for $\mathrm{CO}_{2}$ reduction were often not explicitly weighed. This indicates a suboptimal utilisation of knowledge because of lack of awareness about the possibilities and/or the focus of actors on other issues. As discussed above, in Malburgen there were two examples of the existence of scientific studies involving a comparison of possible options. The effect of input of knowledge was shown to depend on the motives and perceptions of the potential adopters, and the degree to which adequate follow-up was given to the research.

In the renovation of a block of nineteen houses in Utrecht-Noordwest, the municipality had commissioned a consultancy firm to investigate possibilities for solar domestic hot water systems. Because of the rather limited scope of this research, many other options were not seriously considered. Despite the information given by the municipality to the residents about the positive results of the research, and the promise that the municipality would pay $€ 1500$ of the total costs of $€ 2200$ of each solar domestic hot water system, only two of the nineteen owners were interested.

In other projects, scientific studies were not required for options to be adopted. For example, in Utrecht-Noordwest, the choice of district heating was quite logical because a district heating grid was already present.

\subsection{Policy instruments}

One type of policy instrument used is regulation, for example, the Building Decree. This decree specifies $R$-values, a measure for insulation, for parts of the house shell. However, the scope of this regulation is limited. For instance, if a roof needs to be replaced, the new roof should comply with an $R$-value of 2.5 , but the regulation does not require that the roof be replaced. Of the seven renovation projects in which housing parts were insulated, in four cases the minimum requirement (an $R$-value of 2.5) was used, in one case a higher value of 3 was applied, and in two cases exemption was given, making even lower $R$-values possible.

One of the communicative instruments is the National Covenant for Sustainable Building, which was concluded in 1997 between the national government and representative organisations of housing corporations and the energy sector. In this it is stated that in the social rented sector a $\mathrm{CO}_{2}$-reduction of $15 \%$ should be realised in the period $1996-2001$.

The covenant scarcely played any role in the cases and the housing corporations admitted that they did not use it. But this does not mean that the intentions of the covenant were not realised, as in three renovation projects a substantial number of options for $\mathrm{CO}_{2}$-reduction were adopted. One explanation for the limited effect may be that individual housing corporations are not accountable for their contribution to the covenant objectives. These findings are supported by a more extensive evaluation of the achievements in 1998 (van der Laan et al, 2000).

Another important type of communicative policy instrument in the Netherlands are the regional covenants concerning sustainable building, which are signed by municipalities and local actors in the housing sector. in 1998 there were 350 of these covenants (National Dubo-centrum, 1998). Usually the covenants refer to the National 
Packages for Sustainable Building: checklists that contain standard measures and recommendations concerning building materials, water use, the indoor environment, waste processing, and energy conservation.

Regional covenants were applicable to all four projects, but municipalities and housing corporations often did not pay attention to the covenants when agreements about building and renovation were being made. Four possible explanations can be suggested for this:

1. The convenants are not always accompanied by a monitoring mechanism.

2. The covenants do not contain ambitious quantified objectives for $\mathrm{CO}_{2}$-reduction.

3. $\mathrm{CO}_{2}$-reduction is only one of the issues addressed in the covenants: others include water, material use, flexible building, and safety.

4. The legal basis of the covenants is weak. The Housing Act and the Building Decree exhaustively specify the criteria that municipalities must use when they assess appliances for building permits. Thus, the implementation of provisions in the covenants that go further than these criteria depends entirely on the voluntary cooperation of building-sector actors.

Many municipalities are signatories to the Climate Theory for local governments, which can also be viewed as a communicative instrument. The Climate Treaty, which originated as a token of solidarity with people in the Amazon region, calls for a $\mathrm{CO}_{2}$ reduction of 50\% per capita in 2010 (see www.klimabuendnis.org). The cities of Utrecht and Arnhem also signed the treaty. Civil servants in these cities explained that the target of $50 \% \mathrm{CO}_{2}$-reduction is hard to achieve and to monitor. Other studies have also found that municipalities that signed the Climate Treaty are no more active in the field of $\mathrm{CO}_{2}$-reduction than other municipalities (Menkveld et al, 2001).

The overall conclusion is that the municipalities, with the exception of Malburgen, did not play a stimulating role in the investigated projects. This is remarkable given the presence of formal policy plans that formulate quantified targets for $\mathrm{CO}_{2}$-reduction. These targets appear to play little, if any, role in the planning processes.

Within the group of economic instruments, the role of subsidies was investigated. In the demonstration project in Utrecht - Noordwest and the renovation in MalburgenWest, subsidies were a stimulating factor-according to the housing corporations. The subsidies concerned innovative and relatively expensive options for $\mathrm{CO}_{2}$-reduction such as photovoltaic systems and solar domestic hot water systems.

\section{External factors}

The last set of explanatory variables in our model are the external factors. For several reasons, their impact cannot be comprehensively assessed. External factors concern long-term developments, but the periods examined in the case studies are relatively short. In addition, the influence of external factors is mainly indirect and is therefore hard to disentangle from other factors.

The first external factor is the balance of supply and demand in the housing market. One might suppose that the possibilities for shifting costs of options for $\mathrm{CO}_{2}$-reduction onto consumers by means of higher sale prices or rents are greater in times of excess demand. On the other hand, a situation of excess supply may favour the adoption of those options for $\mathrm{CO}_{2}$-reduction that are attractive for consumers because they increase comfort (double glazing, insulation).

In the case studies we could not establish a straightforward relationship between the situation of the housing market and the degree to which options for $\mathrm{CO}_{2}$-reduction were adopted. In Flatstrook Groenwoud and in one of the renovations in Millinxbuurt the housing corporations did not invest in energy efficiency to improve the houses despite the fact that it was difficult to let or sell them. In Millinxbuurt most of the 
houses had been vacant for a long time. A consultation among potential buyers had shown that these people considered the limited insulation and single glazing a problem. In the second renovation in Millinxbuurt, another housing corporation applied good insulation because it had learned from the experience of the earlier project that this positively affects the market position of the houses, even in the case of housing for low-income groups.

The influence of the growing environmental awareness in the building sector, a second external factor, is difficult to establish. Because attention to sustainable building has increased considerably in the $1990 \mathrm{~s}$, we may suppose that more options for $\mathrm{CO}_{2}$-reduction would be adopted in more recent projects. However, the research could not establish a straightforward relationship between the success in terms of adoption and the time at which decisions about adoption or nonadoption were made.

The third external factor is the liberalisation of energy markets. The essence of liberalisation is the introduction of competition in the production, transmission, and distribution of energy. In 2003 or 2004 consumers will have the option of choosing their gas and electricity suppliers. The market for renewable electricity has been free since 2001, and for industry there is already a free market. Energy-production and energy-distribution companies will be privatised. Provinces and municipalities can no longer use them as instruments for their policies (Correljé et al, 2000).

Theoretically, both positive and negative effects of liberalisation are conceivable. On the one hand, liberalisation promises an opportunity to shake up a monopolistic energy market dominated by large-scale technologies. This could provide an opportunity for renewable energy (Collier, 1998). Furthermore, end-users will become more critical of the quality and prices of the energy services, which may also stimulate the use of green energy. Activities in the field of energy conservation may be part of the services to customers. However, energy-saving programmes will probably have a more businesslike character and their costs may be charged to the end-users (Correljé et al, 2000).

On the other hand, liberalisation may lead to lower energy prices, which will adversely affect the cost-effectiveness of options for $\mathrm{CO}_{2}$-reduction. The resources which energy-distribution companies use to implement energy-conservation activities may decline because of the cost reductions (Correlje et al, 2000).

If we assume that energy-distribution companies will see $\mathrm{CO}_{2}$-reduction as being less important to them in a free market, they can no longer be expected to play a role as change agents. The inclinations of building and property-management actors will probably become more important, and the need for municipalities to employ processmanagement strategies aimed at $\mathrm{CO}_{2}$-reduction will increase (Menkveld et al, 2001).

Our case-study projects took place in a period in which energy-distribution companies were being privatised in anticipation of a free energy market. In the case studies, the role of energy-distribution companies varied from proactive (UtrechtNoordwest), to carefully stimulating (Flatstrook Groenewoud), absent (Millinxbuurt), or unconstructive (Malburgen). Based on this variation, no obvious conclusion can be drawn about the positive or negative effects of liberalisation. Nevertheless, the interviews with the energy-distribution companies gave some indications that district heating or other CHP systems are more difficult to realise in the context of a free market.

A final external factor is the culture and structure in the construction industry. The building sector is often characterised as having a defensive, risk-averse, and traditional culture, with little inclination to develop and apply innovations (Priemus et al, 1999, page 28). Most innovations are developed outside the sector, particularly by suppliers. The government also has a dominant influence on innovation in the sector. This has 
led to a situation in which building contractors build to comply with regulations and pay less attention to consumer demands. Because the government defines quality levels, companies can only stand out through fierce price competition (Pries, 1995, pages $151-169)$. These circumstances help us to understand why building contractors do not initiate environmental measures, but does not explain why some projects are successful and others are not.

In conclusion, it is plausible that external factors influence the adoption of options for $\mathrm{CO}_{2}$-reduction in positive as well as negative ways. We cannot, however, explain the differences between the projects from the impact of external factors.

\section{Conclusions and policy implications}

Policies for $\mathrm{CO}_{2}$-reduction often aim to stimulate the diffusion of technological innovations, which need to be adopted in the context of policy networks of interdependent actors. A conceptual model that explains adoption and nonadoption of innovations should therefore include the characteristics of innovations themselves, as well as the interactions between actors. For the housing sector, three sets of explanations were distinguished: characteristics of options for $\mathrm{CO}_{2}$-reduction, factors related to planning processes (process management by change agents, composition of the policy arena, utilisation of knowledge, and policy instruments); and external factors. We focused on the question of what the relative influence is of the factors related to planning processes and of the perceived technical and economic characteristics of options for $\mathrm{CO}_{2}$-reduction on the degree to which they are adopted.

$\mathrm{CO}_{2}$-reduction was shown to play a subordinate role in urban renewal practice, although there are differences between different building and renovation projects. A number of options are being applied, but many opportunities are being missed.

The degree to which options for $\mathrm{CO}_{2}$-reduction were adopted in the investigated projects could not only be explained by their costs or technical characteristics. In some urban renewal projects, relatively cheap options were abdicated and the economic and technical characteristics of options were not considered at all. The actors involved focused on other issues, such as technical housing quality, spatial quality, and social problems. In other situations, measures were applied despite their higher costs.

Additional explanations are related to the planning processes. The most important of these is the role of change agents. However, this role is somewhat different from that described by Rogers (1995), who assumes communication about the advantages and disadvantages of innovations and information transfer to be the main elements of change agents' efforts. The case studies showed that more is needed to make the 'orgware' component of innovations suitable for adoption of the 'hardware' (see section 3). Process management by change agents may involve placing the innovation on the agenda, negotiating with potential adopters about the division of costs, extending the policy arena to actors that were not previously involved, commissioning research into possible options, and making agreements about the implementation.

The findings also illustrate that the success of change agents depends on the motives and perceptions of the other actors in the policy network. However, the influence of the composition of the policy arena is not simply related to the question of whether specific actor groups in the policy network participate or not.

There is room for improvement in the utilisation of knowledge in the planning process. Because options for $\mathrm{CO}_{2}$-reduction were often not considered, it could be argued that nonadoption was the result of inadequate utilisation of knowledge and, more important, lack of awareness about the possibilities. On the other hand, in cases where potential adopters aim to achieve a minimum level of housing quality against low costs, the possible effects of better input of knowledge must not be overestimated. 
Communicative policy instruments, particularly that of the National Covenant for Sustainable Building, regional covenants for sustainable building, and the Climate Treaty for local governments have, in their current form, a limited effect on the adoption of options for $\mathrm{CO}_{2}$-reduction in urban renewal projects. Subsidies, however, are a stimulus for the adoption of innovative options for $\mathrm{CO}_{2}$-reduction. Regulations for energy efficiency are important in encouraging the application of a minimum number of options for $\mathrm{CO}_{2}$-reduction.

External factors, such as liberalisation of energy markets and the state of the housing market, also influence the adoption of options for $\mathrm{CO}_{2}$-reduction, in positive as well as negative ways. We cannot, however, explain the differences between the projects from the impact of external factors.

Our general conclusion is that adoption or nonadoption of options for $\mathrm{CO}_{2}$-reduction in urban renewal projects cannot be explained solely by their technical and economic characteristics, because factors related to planning processes play an important role as well. This does not imply that economic and technical characteristics are unimportant. In some projects, process-management strategies were important because they influenced the perception and assessment of economic costs. In other situations, process management was needed in order for options for $\mathrm{CO}_{2}$-reduction and their economic and technical characteristic to be considered in the first place. However, economic and technical aspects were only part of a wider set of considerations of potential adopters, which also included comfort aspects, the aim to experiment with new techniques, considerations of constructional housing quality, and environmental motives.

It may be argued that there is yet another explanation for the limited degree of adoption of options for $\mathrm{CO}_{2}$-reduction: namely, the urgent social problems that often exist in urban renewal areas. A common view among municipalities is that social problems need to be solved first before issues of global sustainability can be addressed (Andringa, 1998). However, the cases also give examples of situations in which options for $\mathrm{CO}_{2}$-reduction were applied despite the presence of social problems-because there were specific actors who had an interest in $\mathrm{CO}_{2}$-reduction. Furthermore, some objectives of urban renewal projects, such as building houses for higher income groups that can successfully compete on the market, are to some degree compatible with an emphasis on $\mathrm{CO}_{2}$-reduction.

There are other arguments against the view that $\mathrm{CO}_{2}$-reduction should not be an item in situations of social deprivation. In the Netherlands, households with relatively low incomes more often have no insulation. Households with the least financial means, therefore, forego savings in housing costs (van der Waals et al, 2000, page 103). The combination of poverty, poor quality housing, low internal temperatures, and health problems is often referred to as 'fuel poverty'. In situations of fuel poverty $\mathrm{CO}_{2}$-reduction policies can contribute to social goals as well (Bell et al, 1996, page 85).

We conclude this paper with some remarks about policies for $\mathrm{CO}_{2}$-reduction in housing, taking into account the implications for other (European) countries. There is evidence that in other countries, such as Denmark and Germany, also, local energy policies directed at housing fail to live up to expectations (Elle et al, 2002). And in other respects also, the Dutch situation is not unique. In many countries, actors in the energy and housing sectors have considerable freedom to make decisions relatively independently from the (local) government. Furthermore, they are susceptible to similar developments, such as liberalisation of energy markets and trends in the housing market. Furthermore, the fact that $\mathrm{CO}_{2}$-reduction has to compete with other more immediate concerns in urban renewal areas is applicable in many situations. 
Policies in the Netherlands, especially those concerning the existing housing stock, rely heavily on instruments that appeal to the individual initiative and voluntary cooperation of municipalities, building-sector parties, house owners, and energy-distribution companies. Some findings of the case studies suggest that voluntary cooperation may be successful if there are 'change agents' that take the initiative. Local process-management strategies could aim to involve potential adopters of options for $\mathrm{CO}_{2}$-reduction in the planning process and to utilise knowledge to raise awareness about the possibilities. Elle et al (2002) illustrate the importance of process management and the limitations of traditional policy instruments - such as regulation, subsidies, or providing general information-in the Danish and German situation. In addition, they underline that local authorities can make use of new market conditions by finding specific opportunities with the actors involved, taking the motives of these actors into account (Elle et al, 2002).

However, reliance on local process management is only warranted if potential adopters of options for $\mathrm{CO}_{2}$-reduction are susceptible to such policy initiatives. This would be the case if they perceive $\mathrm{CO}_{2}$-reduction, or other advantages related to options for $\mathrm{CO}_{2}$-reduction, to be important and worth investing money in. The study showed that this is not always the case. In all actor groups, there are innovators as well as those with little inclination to adopt options for $\mathrm{CO}_{2}$-reduction.

Therefore, in addition to local process management, national top-down strategies are needed to influence actors who are not predisposed to voluntary approaches or who do not participate in planning processes. Such strategies could include strong financial incentives, or regulations for energy efficiency of existing houses. Although legal prescriptions may be difficult to implement because of the diversity of the housing stock, their major advantage is that they can be effective for all houses, whereas voluntary instruments usually only stimulate the front runners. Another reason to apply instruments with a wide scope is that urban renewal processes only concern part of the housing stock. Therefore, a policy approach that leaves the adoption of options for $\mathrm{CO}_{2}$-reduction entirely to local actors is not to be preferred. This conclusion is related to circumstances found in many countries, particularly the relative autonomy of actors in the housing and energy markets from local governments, and the varying degree to which these actors perceive $\mathrm{CO}_{2}$-reduction to be important. Therefore, we may assume that it has a more general value beyond the situation in the Netherlands.

Acknowledgements. This study was made financially possible with support from the Ministry of Housing, Spatial Planning and the Environment, the National Institute of Public Health and the Environment, and the Urban Research Centre Utrecht. This paper reports the results of a study conducted at Utrecht University and is not meant to communicate the policy of the Ministry of Housing, Spatial Planning and the Environment.

\section{References}

Andringa J, 1998, “The influence of Local Agenda 21 on local policy and the quality of decisionmaking: the pioneer city of The Hague", in Participation and the Quality of Environmental Decision Making Eds F H J M Coenen, D Huitema, L J O’Toole (Kluwer, Dordrecht) pp $107-123$

Bell M, Lowe R J, Roberts P W, 1996 Energy Efficiency in Housing (Avebury, Aldershot, Hants)

Boonekamp P G M, van Dril A W N, Jeeninga H, Menkveld M, van Arkel W G, 2000 Milieukosten van genomen besparingsmaatregelen [Costs of energy saving measures] Energieonderzoek Centrum Nederland, PO Box 1, 1755 ZG, Petten, www.ecn.nl

Capello R, Nijkamp P, Pepping G, 1999 Sustainable Cities and Energy Policies (Springer, Berlin)

CBS/RIVM, 1999 Milieucompendium 1999: het milieu in ciifers [Environmental compendium 1999: facts and figures about the environment] CBS [Stratistics Netherlands] and Rijksinstituut voor Volksgezondheid en Milieu, Samsom H D Tjeenk Willink bv, PO Box 2400, Alphen aan den Rijn, www.kluwer.nl 
Collier U, 1998, “Liberalisation in the energy sector, environmental threat or opportunity?", in Deregulation in the European Union: Environmental Perspectives Ed. U Collier (Routledge, London) pp $93-113$

Correljé A, Keers G, de Wildt R, 2000 OEI in de toekomst. Een strategische verkenning in een liberale omgeving [Optimal energy infrastructure in the future. A strategic exporation in a market-based environment] Erasmus Studiecentrum voor Milieukunde, Rotterdam and RIGO Research en Advies BV, Amsterdam

Crommentuijn L E M, Verbeek E D M, 1999 Prognose Milieu-effecten Duurzaam Bouwen. Kabinetsbeleid tot eind 1997 in Woning - en Utiliteitsbouw [Prognosis environmental effects sustainable building. The cabinet's policy for housing and office construction until the end of 1997] Rijksinstituut voor Volksgezondheid en Milieu, Bilthoven

DGVH, 1999 Volkshuisvesting in ciifers [Facts and figures about housing] DGVH [DirectorateGeneral for Housing] Ministerie van VROM, Den Haag

ECN/RIVM, 1998 Optiedocument voor emissiereductie van broeikasgassen. Inventarisatie in het kader van de Uitvoeringsnota Klimaatbeleid [Option document for emission reduction of greenhouse gases. Inventory in the context of the memorandum on climate change policy] Energieonderzoek Centrum Nederland, PO Box 1, 1755 ZG, Petten and Rijksinstituut voor Volksgezondheid en Milieu, Bilthoven, www.rivm.nl

Elle M, van Hoorn Th, Moss T, Slob A, Vermeulen W J V, van der Waals J F M, 2002, "Rethinking local housing policies and energy planning: the importance of contextual dynamics" Built Environment 28(1) $46-56$

Kickert W J M, Klijn E-H, Koppenjan J F M, 1997, "Introduction: a management perspective on policy networks", in Managing Complex Networks. Strategies for the Public Sector Eds W J M Kickert, E-H Klijn, J F M Koppenjan (Sage, London) pp 1 - 13

Marin B, Mayntz R (Eds), 1991 Policy Networks: Empirical Evidence and Theoretical Considerations (Westview Press, Boulder, CO)

Menkveld M, Burger H, Kaal M B T, Coenen F H J M, 2001 Lokaal klimaatbeleid in de praktijk: benutting van het speelveld, de invloed van trends en integratie van klimaatzorg in gemeentelijk beleid [Local climate change policy in practice: utilisation of possibilities, the influence of trends, and integration of climate change considerations in municipal policy] Energieonderzoek

Centrum Nederland, PO Box 1, 1755 ZG, Petten and Universiteit Twente, Enschede, www.ecn.nl

Moorman S A H, 1999 Inventarisatie grote herstructureringsprojecten in de bestaande woningbouw. Thema: energie [Inventory of large urban renewal projects in the existing housing stock. Theme: energy] Centrum voor energiebesparing en schone technologie, Oude Delft 1802611 HH, Delft, www.ce.nl

National Dubo-centrum, 1998 Dubo-convenanten in ontwikkeling. Een handleiding voor en informatie uit de praktijk [Sustainable building covenants in development. A manual for and information from practical application] (Aeneas, Best)

Priemus H, van Bueren E, Blaauw K, Hasselaar E, Klunder G, Veentjer M, 1999 Institutionele belemmeringen voor factor 20 bij besluitvorming over duurzaam bouwen [Institutional barriers for 'factor 20' in decisionmaking about sustainable building] (Delft University Press, Delft)

Pries F, 1995 Innovatie in de bouwnijverheid [Innovation in the construction industry] proefschrift Erasmus Universiteit Rotterdam (Eburon, Delft)

Rogers E M, 1995 Diffusion of Innovations 4th edition (The Free Press, New York)

Scharpf F W, 1978, "Interorganizational policy studies: issues, concepts and perpsectives", in Interorganizational Policy Making: Limits to Coordination and Central Control Eds K Hanf, F W Scharpf (Sage, London) pp 345-370

Slot B J M, Poel A, Scholte W K, 1998 KWR '94 - '96 Analyse Energie en Water [Monitoring of housing quality '94 - '96, analysis for energy and water] Damen consultants, PO Box 598, 2600 AN Delft, www.damenconsultants.nl

Smits R E H M, 2000 Innovatie in de universiteit [Innovation in the university] inaugural lecture, Faculty of Geographical Sciences, Department of Science, Technology and Innovation Management, Utrecht University, Utrecht, www.nwi.uu.nl

Teisman G R, 1998 Complexe besluitvorming. Een pluricentrisch perspectief op besluitvorming over ruimtelijke investeringen [Complex decisionmaking. A pluralisatic perspective on decisionmaking about physical planning projects] (Elsevier, Amsterdam)

van der Laan P C H, Klein V, van den Bor W, de Zwaan A, 2000 Monitoringsresultaten Dubo convenant, peiljaar 1998 [Monitoring results of the covenant for sustainable builing, 1998] (Atrivé, Zeist) 
van der Waals J F M, $2001 \mathrm{CO}_{2}$-reduction in Housing, Experiences in Building and Urban Renewal Projects in The Netherlands dissertation (Rozenberg Publishers, Amsterdam)

van der Waals J F M, Vermeulen S M J, Vermeulen W J V, Glasbergen P, Hooimeijer P, 2000

Energiebesparing en stedelijke herstructurering: een beleidswetenschappelijke analyse [Energy conservation and urban renewal: a policy science analysis] DGVH [Directorate-General for Housing]/NETHUR [Netherlands Graduate School of Housing and Urban Research] Utrecht

Velthuijsen J W, 1997 Sustainability and Energy Use: A Challenge to the Economist inaugural lecture, University of Amsterdam (Vossiuspers AUP, Amsterdam) 
